\title{
Market Liberalisation and the (Un-)making of the 'Perfect Neoliberal Citizen': Enactments of Gendered and Racialised Inequalities Among Peruvian Vendors
}

\section{Cecilie Vindal Ødegaard}

Peru was not part of the so-called Pink Tide in Latin America, but opted for deepening its neoliberal orientation initiated with Alberto Fujimori's policy reforms in the 1990s. Since then, governments have envisioned modernisation and progress through an emphasis on market liberalisation and implemented tax, royalty and policy regimes accommodating for privatisation and foreign investments. Social reforms initiated in the 1990s took the form of 'liberal-informal' regimes based on (partial or total) privatisation of the financing and provision of services, as well as statefinanced social programmes targeting particular segments of the population (Rousseau 2007:97). Alongside these developments, small-scale businesses among the poor were increasingly encouraged by the state, NGOs and commercial enterprises through the provision of micro-credit arrangements and training in marketing skills. Through this expansion of neoliberal rationality, governments aimed to instigate 'development'

C.V. Ødegaard $(\bowtie)$

University of Bergen, Bergen, Norway

(C) The Author(s) 2018

M. Ystanes, I.Å. Strønen (eds.), The Social Life of Economic

Inequalities in Contemporary Latin America, Approaches to Social

Inequality and Difference, DOI 10.1007/978-3-319-61536-3_8 
through the promotion of entrepreneurship and trade also among the poor. During the presidency of Alejandro Toledo (2001-2006), Peru signed several free trade agreements facilitating overseas, bilateral trade by eliminating trade obstacles, consolidating access to goods and services, and fostering private investments between bilateral partners. From the turn of the millennium and onwards, Peru experienced significant economic growth due to the boom of primary materials. Yet inequalities persisted, and during presidential campaigns in 2006 and 2011, Ollanta Humala built his political platform by promising to create a more equitable framework for distributing wealth from the country's natural resources. Before his presidency, Humala was thus closely affiliated with other Pink Tide leaders in Latin America, although his time in office (2011-2016) resulted in political continuity rather than change. Hence inequalities in Peru have persisted, and thousands of Peruvians still struggle to find a way out of poverty, often by relying on precarious forms of work at the margins of the formal economy.

This chapter is an attempt to analyse economic processes in Peru from the perspective of women vendors. It examines how vendors manoeuvre between varying degrees of formality/informality, and how identity markers related to gender, 'race' and class are in different ways made relevant in their everyday manoeuvres. Focusing on enactments of identities at the crossroads between improvisation and formalisation, the chapter illustrates how women's everyday economic tactics are shaped by Peru's particular socio-economic configurations under neoliberal regimes. In this regard, and considering how economic operations are socially embedded and informed by social relations and institutions of various kinds (Polanyi 1944), the chapter argues that the (in)formalisation of economic activities is informed by post-colonial legacies and existing social relations and institutions. Processes of (in)formalisation hence play out in spaces that are created through, and often contributing to reinforce, relations and categorisations connected to gender, 'race' and class. Against this backdrop, the question of neoliberal policy and in(formalisation) in the Peruvian context needs to be highlighted through an ethnography of the class, ethnic and gender relationships in which these processes are actualised. Indeed, the work of vendors, and especially the entrepreneurial chola, epitomises the development and effects of neoliberal politics in post-colonial Peruvian society, by actualising and reproducing class, 'race' and gender categories, stereotypes and relationships. The so-called chola can be seen both to resist and to convey the intersections between class, race and gender in Peruvian society, as she is ambiguously positioned and envisioned in-between racialised and class-based categories such as indigenous and mestizo, rural 
and urban. Living the life of the urban poor, the chola maintains her rural ways and relations, while making a living through trade and entrepreneurship. In many ways, the chola may appear as the 'perfect neoliberal citizen', as hard-working and self-made, and accommodating her own quest for social mobility to growing demands of growth, flow and consumption. Yet the entrepreneurial chola seeks to develop her economic strategising and tactics on her own terms. The chapter therefore demonstrates how vendors rely on relational and symbolic resources in their economic endeavoirs.

The chapter builds upon several periods of fieldwork in Peru since 1997 (with subsequent fieldworks in 2001, 2007, 2011 and 2016), when I conducted research among vendors and contrabandistas associated with the marketplace La Feria Altiplano ${ }^{1}$ in the city of Arequipa. At the Feria in Arequipa, most vendors are bilingual Quechua- or Aymara- and Spanish-speakers, primarily women. The goods offered at the Feria are agricultural products, textiles and artisan crafts, pirated CDs and computer software, as well as industrial and electronic articles. Many of these goods are smuggled from Bolivia or Chile, often produced in China. The Feria was established after several years during which a group of vendors had occupied land in different areas of the city for purposes of vending. Since they initiated these unauthorised markets in the 1980s, the vendors were repeatedly fined or removed by the police. These difficulties resulted in the creation of an association of vendors and finally their acquisition of an area that they formally bought in 1999. While the association has thus acquired land titles - at least in partand most members pay for a license, the vendors do not pay taxes, and many of them also bring undocumented merchandise from across the border, referred to as contrabando. Those who bring goods like this, generally selfidentify as contrabandistas (smugglers), and proudly so. Leaders of the association take responsibility for paperwork and communication with the municipality, and these positions are often held by men. This is despite the fact that the majority of members are women, and is related to the expectation that leaders should be experienced with reading and writing.

Considering that many vendors have a background from the Andean highlands and limited economic and educational resources, their work in vending reflects the structural inequalities in Peruvian society and the intersections between class and a racialised hierarchy. For most, vending has been and continues to be a precarious means of making ends meet but, as one of my interlocutors said, 'at least it makes some coins circulate through my hands'. Others-especially contrabandistas - may earn more than the minimum salary, and some have managed to expand and make new investments, for instance in land, trailers or buses. 


\section{Emerging 'Cultures of Informality'}

The mid-century migration boost in Peru and the land occupations that followed aroused anxiety for delinquency and social breakdown among the urban elites. In the city, migrants from the Andes were considered 'matter out of place' in the perspective of the upper and middle class, and the migrants' presence disturbed the racialised spatial dichotomies of ruralurban, indigenous-mestizo. Women vendors came to occupy a particularly ambiguous position in relation to these racialised dichotomies and stereotypes, as their ways of living disturbed dominant norms of genderappropriate behaviour too. Not complying with the dominant norms that feminine realms should be hidden away from the eyes of strangers and that the public sphere is the domain of men (Weismantel 2001:47, Seligmann 2004), women vendors and their activities were regarded as chaotic and unhygienic - and market places as incompatible with the desire to modernise Peruvian cities. Seen from the perspective of social scientists in Peru as elsewhere in Latin America, in contrast, these informal economic ventures (including the land occupations) were seen to involve new claims for citizenship among the urban poor (Roberts 1995), and to represent a form of 'insurgent citizenship' with a potential to alter the poor's terms and conditions for citizenship (Holston 2008). Poor people's initiatives at the margins of the formal economy were thus seen as heralding a new era of contestation against the legal institutional apparatus, which has given rise to what is often referred to as 'cultures of informality' (Matos Mar 1984).

With the economic down-turn in Peru during the 1980s, informal economic ventures gained increased importance as a source of livelihood for rising numbers of urban poor. Migration to Peruvian cities continued during the 1980s, also due to the war between the guerrilla movement Sendero Luminoso and the military, as thousands of people were forced to flee from rural areas to the cities. The existing labour surplus in the cities was augmented with Fujimori's austerity measures (the so-called Fuji-shock) in the 1990s, as structural adjustment programs, privatisation and dramatic cuts in public spending further exacerbated the need for alternatives to waged labour (see also Stensrud, (Chap. 10) this volume). The economic set-back was to affect Peruvian society severely, while other Latin American countries involved in similar processes tried to soften the negative effects of adjustments through the introduction of safety nets. Among people living in the shantytowns of Peruvian cities, many, both men and women, turned to different forms of self-employment-men sometimes combining taxidriving with short-term employment in construction, and women in 
different kinds of informal work and vending. Among my women interlocutors, some first started working as domestic servants, in textiles factories or as day labourers at the farms surrounding Arequipa, but later many of them turned to vending due to low payment and a strict labour regime in other forms of low-skilled work.

As indicated in the introduction, the neoliberal promotion of entrepreneurship in Peru does not exist in a vacuum, nor does women's predominance in the country's - often informal-market places. There are indeed long traditions in the Andes for barter and trade, and for women's involvement therein, so vending is not necessarily something they first learn in the city, or by participating in micro-credit arrangements. Women's involvement in vending can also be seen in light of historical traditions for women in the Southern Andes to be responsible for barter and vending, due to their traditional responsibilities for herding and commercialising the produce (Harris 2000). The promotion of entrepreneurship from the part of recent governments, often directed at women in particular, have nonetheless contributed to reinforce the tendency that women occupy precarious and low-income forms of employment. The targeting of women also reflects how women have often been seen as tools for development because of their link to issues of reproduction and domestic space (Ewig 2010:7; Ødegaard 2010). According to one of my interlocutors, vending and contraband is a 'plan for women. If a man gets involved, people will say he is doing women's work'.

Policies for the formalisation of unauthorised economic activities and use of land have been introduced alongside the promotion of entrepreneurship. The government of Fujimori established specific institutions for this purpose, such as Commission for the Formalisation of Informal Property (COFOPRI), and succeeding governments followed up with this and similar land-titling projects aiming to promote 'development', security for owners and a more effective land market. These initiatives form part of a continuing expansion of a neoliberal rationality, by facilitating the commodification of land and contributing to fortify already existing fissures along class lines, due to the high cost of formalisation and rising prices of land (Larkins 2015:156). It indicates how an increasing significance ascribed to formality and the legal (Sieder et al. 2005) is central for the liberalisation of markets worldwide, entailing mechanisms through which contrasts between 'licit' and 'illicit' are both intensified and continually blurred (Comaroff and Comaroff 2006). In Peru, policies of formalisation have been recommended by economists like de Soto $(1989,2001)$, who argued that formal ownership among the poor would promote development, 
by contributing to the integration of unauthorised economic activities into the economy at large. As noted by Scott (1998), formality is indeed part of making society legible (Scott 1998) — and may represent a prerequisite for increasing tax revenues and improved welfare services. De Soto's concern with formalisation, however, appears to be related primarily to its 'property effects', i.e. that formalisation would promote economic activities and development through the security of formal ownership. Despite the fact that formalisation may enable people to legally use and protect their resources, the terms and conditions can nonetheless create and fuel other processes that may lead to increased dispossession and marginalisation (Mitchell 2002). To think otherwise would be to overlook an important insight from economic anthropology; that the economy must be understood as instituted through societal relations and institutions of various kinds (Polanyi 1944).

In a study of Lima's contraband markets, Gandolfo (2013) describes how vendors explicitly evade formality, and resist attempts by state bureaucracies to draw them into regimes of regulation. Although the vendors' resistance carries costs and risks, she argues that they nonetheless value more highly the freedom and autonomy that informality affords. One of the key freedoms of informality, she notes, is to subsume profit to particular modes of sociality. By investing in market colleagues, kin, earth beings, and saints, wealthy vendors give time and money to 'reciprocal relations and forms of consumption that limit the accumulation of wealth' (ibid.: $280)$. As I have illustrated elsewhere $(2010,2016)$, this intense cultivation of social relationships at the margins of the formal carries similar importance among vendors in Arequipa. This does not necessarily mean that vendors evade formality, since actors who operate informally may also seek formalisation (see also Holston 2008). It is therefore necessary that we analyse how people may also seek to mediate between informality and the demands of formalisation. A useful approach to this end may be found in Bear's (2014a, b) emphasis that we explore ethnographically the divergent social rhythms of different institutions such as those of production, consumption, finance, social reproduction and governance. In particular, she exhorts us to explore how the divergent social rhythms of different institutions may create conflicts and uncertainty at the level of the human lifecourse, and how people seek to mediate between such divergent social rhythms through acts of labour. We must therefore include into our enquiries also the acts of labour that are not necessarily recognised as such, such as the issue of informal labour, in considering the social formation of capital and wealth. Bear's concern is not to problematise the boundaries of formality and informality, or the many intersections between formalised 
and unauthorised economic activities (Comaroff and Comaroff 2006), but to explore the acts of labour that cross-cuts such distinctions. While informal labour represents aspects of inequality that are often invisible and unaccountable to state institutions, informality is nonetheless part of social relations that significantly contribute to the accumulation of wealth in society (2014a:643). Considering how key aspects of inequality are played out as well as reproduced through different kinds of informal or unrecognised work, the following section examines how vendors draw upon key identity markers and relations in their economic tactics. It includes an exploration of how vendors deal with and mediate between official demands and other modes of sociality, and hence how economic processes are informed by existing social relations and institutions. These economic processes play out in spaces that are created through, and contributing to reinforce, relations and categorisations related to gender, 'race' and class.

\section{The Social Embeddedness of Trade}

With its location on the slopes of the Andes and as the second largest city in Peru, Arequipa is an important regional distribution point for trade between highland and coast, and a convenient location for importation and distribution of goods from Bolivia and Chile. The contrabandistas travel every week to bring merchandise in large quantities to the retailers at market places in Arequipa. Some contrabandistas also have their own market pitches, where they also run retailing businesses.

My interlocutor Rosaria (which is the pseudonym I have given her) is among the vendors who have been part of the Feria association in Arequipa since the beginning. Like many of the other vendors, she is from a community outside Puno, and came to Arequipa as a young girl. With only a couple of years of primary school, she first worked a few years as a domestic servant before she started selling sweets in the streets and later became part of the association. For a long time Rosaria lived with her family in a shack on occupied land in Arequipa's outskirts, and when her husband was laid-off from his job in 2000, she started to bring contraband from Bolivia in the hope of increasing her earnings.

Several scholars have noted how women are further marginalised and impoverished through their involvement in vending and informal work (e.g. Kabeer 2010). While informal work may indeed contribute to reproduce structural inequalities, the significance of earnings made from vending should not be underestimated. Like her mother, Rosaria's daughter Dorothea also turned to trade and contraband, after having worked a few 
years at a textile factory. While Dorothea used to be paid the minimum salary when working in the factories, she earns a lot more now, as a vendor. As a result, she has managed to construct a big house in one of Arequipa's shanty towns and to send her son to a private school. Indeed, Dorothea's earnings gradually resulted to be more predictable and sometimes even higher than her husband's. He used to work in construction, and although earning a monthly salary, his earnings were unpredictable since job contracts were only for three months. After a while her husband grew tired of this and decided to accompany Dorothea in business. The income earned from vending may thus represent the more steady income of a household, and upon realising this some men join their wives' businesses. At the Feria, there are also vendors who have university education, but who, due to low pay, have decided to work in vending. This situation illustrates how weak regulation of labour conditions, combined with low pay in the public sector, makes vending the better alternative for many.

While Dorothea and her mother trade in groceries, many contrabandistas prefer to work with clothes since the gain per unit is higher compared to other goods. Clothes are also easier to hide than many other goods. Contraband clothes are sold without tags; the contrabandistas remove them to make customs and fiscal authorities believe that the clothes are not meant for commercial sale. Victoria is one of my interlocutors who not only sells textiles from her own pitch at the Feria, but also travels to collect goods. Victoria's husband is a teacher, and often comes to help his wife in her business. When she is travelling, he sells from her pitch. Their daughters sometimes assist, too. Victoria is originally from the department of Puno, from a community close to Desaguadero and the border with Bolivia. During her journeys to Desaguadero and on her way back to Arequipa, she always stops to visit with relatives in the area. This gives her a good opportunity to hide the garments without being disturbed. Desaguadero is an important town for the transport and distribution of contraband, as it is located just at the delineated border between Peru and Bolivia. Desaguadero is often referred to as tierra de nadie (no man's land), referring to the absence of state control in areas where vending is alveady institutionalised. In and around Desaguadero, people bring their merchandise across the border without particular interference, or by paying bribes (coyma).

The fact that most of these enterprises are kinship-based and involve the labour input of partners, children and other kin helps vendors maintain the everyday operations of their businesses and accommodate for the risks. Vending demands long working hours and a lot of travel, so there is 
a division of labour among household members as to who sells from the pitch and who travels. Many vendors have learned the skills of vending from their parents or older kin, and it may be difficult to enter these businesses without such connections. The contrabandistas often travel together in small groups, cooperating about where to buy goods, and how to avoid getting caught. Sometimes they make joint investments in particular commodities in order to benefit from the better prices given when buying por mayor. Like Victoria, many contrabandistas have kin living in the border areas. Kin and local farmers often help the contrabandistas, providing information and storage for goods. The economic strategising of vendors thus draws upon socially and spatially embedded relations and identities, and reinforcing the constitution of this kind of work as defined by key inequality markers (class, 'race', gender).

While often seeking to evade formality, as suggested by Gandolfo, vendors may also attempt to strike a balance between formality and informality, in the sense that they seek to operate formally enough not to constantly get caught, and informally enough to actually earn money, as is illustrated in the case of Victoria. While Victoria sometimes goes to Lima to buy merchandise from the authorised importers operating in Gamarra, these legal clothes are more expensive. More often, when she has less capital to invest, Victoria travels to the border areas, instead, for contraband. Since transporting contraband can be difficult, she brings only a few garments at a time. To avoid confiscation at customs, she might wear the clothes (especially the bigger, heavier garments), hidden underneath her own clothes, or mixes them with other things in a big bag. She removes tags, so that customs officers do not notice that the clothes are new, but view them as personal items. From Lima, in contrast, it is possible to transport large quantities from a legal importer, with taxes paid and an RUC-number (shop registration number). Victoria's different tactics for bringing merchandise to Arequipa illustrates the considerations contrabandistas make regarding formality and informality and the different routes for obtaining contraband versus documented goods. Like Victoria, some contrabandistas prefer to bring goods legally if they have sufficient capital, but turning to contraband in cases when they are in lack, and hence combining their trade in contraband goods with documented merchandise. It shows how vendors do not necessarily resist formality, but that formality requires more capital to invest and often gives vendors a lower income compared to the trading of undocumented goods. Official demands of formalisation thus contain the potential of exacerbating inequalities. 


\section{Ambiguous Status as Work}

Several scholars have observed how market women are seen as vulgar, indecent and somewhat dirty figures by the 'educated' classes, as 'matter out of place' within dominant gender ideologies, and evoking the dread of the indian, and especially of the indian woman who transgresses symbolic boundaries (Seligmann 2004; Weismantel 2001; Rivera Cusicanqui and Arnold 1996). The work of women vendors thus involves not only risk and uncertainty, but often humiliating and abusive treatment, also from public functionaries. Despite this, it seems as if public functionaries have also typically shown a certain degree of tolerance for these activities, an issue I return to.

What appears as the transgressive aspects of vendors' practices is illustrated by the representation of these women as somewhat 'men-like' and 'out of proportions', in a way that was captured in the program Paisana Jacinta, broadcasted by Latina Television. In the program, a male actor plays the role of Jacinta, depicting an indigenous woman trying to accommodate to urban ways in Lima. More than simply illustrating racial and gendered stereotypes connected to the chola, Paisana Jacinta embodies the social uneasiness spurred by the image of a woman who struggles to make ends meet. Now, while the presence of women vendors in urban market places is indeed considered disturbing by many, their market work is at the same time regarded as an extension of domestic and reproductive activities. Market work thus has an ambiguous status as work. During my first fieldwork, when I asked women in a shanty town in Arequipa about their work, many responded that they did not work since there were no jobs to get. Later I learned that the same women worked as vendors. In this manner, they seemed to consent with the view that vending is not really 'proper work'. I also learned that many women prefer to work in vending due to, among other things, the possibility to bring their children along to the market-something which is difficult in other forms of work. Market spaces are not regularised through norms or supervisors to the same extent as other workplaces, and especially small children can be looked after while working at a market pitch. Also contrabandistas who travel to bring goods from Bolivia or Chile often bring children along on their journeys. Indeed, vending represents an opportunity to both look after the children and earn money at the same time. These dimensions reinforce the perception of vending as not really 'proper work', despite the fact that women's vending activities often represents an important contribution to their households' 
income. As argued by de la Cadena (1995), perceptions of vending in the Andes are informed also by the notion that women are regarded as more indian than their male counterparts. As women sell products from the highlands and often wearing Andean clothing and braids, women's work in trade is often considered of less value than that of men. It indicates how vending is imagined and constituted through particular, key markers of inequality.

Several feminist scholars have demonstrated that the dichotomous association of women with the domestic and men with the public sphere serves as a way to mask structural features of employment, to undercommunicate and/or devalorise women's labour (Leacock 1972; Sacks 1974; Yanagisako 1987). Binaries like public/domestic and production/reproduction have thus come to be seen as a disguise for power mechanisms and culturalspecific gender ideologies. Babb (2001) has argued that vendors in the Andes do not operate within what can simply be considered a 'reproductive' sphere or by selling small-scale food products, by demonstrating how vending in the Andes may also involve mass-production. Thus criticising the widespread view of market women's labour as strictly reproductive and distributive, Babb stressed how different kinds of food processing take place in the market that would have been interpreted as productive if done in a factory. Indeed, vendors add economic (as well as cultural) value to their work in a manner that not only resists the productive/reproductive binary, but throws such binaries into a critical light, as veiling the interconnectedness of these social processes and the significant role of vendors in the national economy (Babb 2001). It illustrates how the monetary significance of vending, both for individual households and for the national economy, is skewed due to its construction as a feminine realm. As I will return to, the image of vending as a feminine realm and extension of household activities may nonetheless represent a resource in vendors' tactics and encounters with public officials.

Several unauthorised markets have continued for years without particular interference, and many contrabandistas have brought goods across the borders throughout their often long working careers. On occasion their goods have been confiscated, but not frequently enough to prevent them from continuing their businesses. It is of course impossible, however, to generalise regarding the official interference in vending and contraband, since such interference has varied over time, and with the kind of activity and merchandise. While there have been periods when vendors have experienced significant persecution and abuse, my impression, since my first 
fieldwork in 1997, is that there has also been a certain degree of toleration for vending and contraband, especially under the presidency of Fujimori. The frequency of official interference seems to have increased over the recent years though, although with significant variations across regions. During my fieldwork in 2011, interferences at marketplaces were becoming more frequent in Lima than in Arequipa and Puno, although the controls along the roads, especially before Arequipa, had become a lot stricter than before. Some public functionaries also seemed to find it difficult to intervene in these businesses, and explained their non-interference by stressing that 'there are no jobs to get anyway'. As underlined by a legal advisor I interviewed in Arequipa: 'it is difficult to do anything, because people get angry and will ask for an alternative'.

\section{Enactments of Gendered and Racialised Identities}

In recent years, Rosaria's daughter Dorothea has had her merchandise confiscated several times. On one such occasion, her husband criticised her for not being able to avoid such interference and for thus letting her goods be confiscated. As we met a few days later, Dorothea said that: 'he thinks it is easy, but it is not easy at all, it is not as if you can just take some products and then you earn'. Many vendors similarly stressed the struggle, suffering and sacrifice that vending involves, but simultaneously emphasising that they just have to go on 'with their eyes closed', in order to support their children. In this and other ways, vendors evoke a notion of motherhood in terms of suffering and sacrifice, a notion that has been discussed in literature from Latin America as central for making political claims (Goddard 2000), as they plead that vending is their only way to earn a living and feed their children. By actualising these notions, more specifically the poor and marginalised mother, vendors try to make interference more difficult for the public functionaries.

Some contrabandistas bring second-hand clothes into Peru by travelling to Iquique in Chile for clothes shipped from the USA, Europe or Japan. These women are called cachineras (referring to discarded things), and sell from the streets close to the Feria. The commercialisation of second-hand clothes is a contested issue though. In 2005, the importation and sale of second-hand clothes was prohibited by law, in what was considered a halfhearted attempt to protect the national textile industry. This commercialisation nonetheless continues, as vendors move their pitches from place to place, or place themselves hidden in the middle of other vendors who sell 
legally. At a huge let-out sale for second-hand clothes hidden in a parking lot, I encountered a group of vendors selling clothes from huge plastic bags to retailers from neighbouring markets. One of them explained that some women from Puno take care of the importation from Chile and that these women are the ones in charge of the whole business. 'These women can earn money from anything', she said. 'They even fight the police. If they were men, they would have been put to jail. But not with the women. They [that is, the functionaries] have more respect for women. For this reason vending is easier for women'.

This notion, that functionaries have 'more respect for women', hinges upon an idea about woman as mother. It indicates the significance of particular constructions of womanhood for how vending and interferences in vending are negotiated. This notion, deliberately associating womanhood with domestic chores and disassociating them from commercial activities and regulation, may allow women to be involved in contraband or other businesses at the margins of the formal, perhaps even giving women a relative advantage over men. Such constructions of womanhood may even work to reinforce claims to local sovereignty in practices of vending and cross-border trade. While this notion of womanhood as motherhood may, in many cases, contribute to facilitate women's involvement in vending, it is also related to the devalorisation of women's work, that women's work is not regarded as important enough for the authorities to interfere, due to a view that it is men who do the real work and women's work is seen as 'extra' (Lazar 2008). In a similar vein, Carsten (2004) has noted how most kinds of work are considered legitimate as long as it is related to household subsistence. This is not to say that women vendors are not exposed to abuse by public functionaries, but rather is to stress how constructions of womanhood may affect the ways in which official interferences are negotiated.

In encounters with fiscal, customs or police authorities, vendors may also represent themselves as 'ignorant', claiming that they did not know it was illegal, that they are humble and cannot read and write, and that the officials must understand and forgive them. When referring to what she regards as the sometimes bad ways in which vendors are treated by the customs and fiscal authorities, one vendor for instance said that 'although we are humble and do not know, they [that is, the functionaries] ought to respect us'. In this and other ways, vendors and contrabandistas may construct an image of themselves as humble and 'not knowing'. This does not mean that they not also criticise, mock or manipulate public functionaries 
though, and contrabandistas sometimes fight the custom officials in order to pass with their goods, or they destroy their goods by pouring petrol on so that the goods will be of no value for the officials either.

Racial categorisation too is made relevant in vendors' encounters with public functionaries. Dorothea for instance said that 'I have this look [referring to herself as a chola]. The customs know immediately when they see me'. Her colleague Juana suggested that she should start dyeing her hair, in order to look like a tourist. In this and other ways, appearances are made important in encounters with public functionaries-and identity markers may also be changed with such encounters in mind. Juana herself works as a cachinera. When she and her cachinera colleagues travel to bring merchandise they try to look like tourists, making sure to be nicely dressed with make-up and all, and travelling with huge, stylish suitcasesin contrast to the more common bultos (bundles). In this manner, some contrabandistas try to mimic the looks of tourists or mestiza women. It is also not uncommon that contrabandistas manipulate their identity papers, and some even change their surnames to more Hispanic-sounding ones, in order to avoid the prejudice that a Quechua or Aymara surname may result in. There are other contrabandistas though, who refuse to show their papers when being stopped by police or customs agents. As we were discussing the dangers of getting caught when bringing contraband, Juana stressed that 'you have to make an effort never to show them your documents, and never give your name'. Vendors may thus not only seek to hide their practices to avoid official interference, but also, once caught, try to make themselves 'illegible' to state institutions by refusing to provide documentation.

As illustrated in the case of the cabineras, vendors seek to make themselves 'visible' in very specific and deliberate ways, by making use of identity markers such as clothes, and hence drawing upon particular racialised and gendered stereotypes in their attempts to avoid interference. While some try to dress up as mestiza women, others wear the traditional manylayered skirts (polleras), braids and bowler-hats on their journeys, and in this manner emphasising an image of indigenous farmer-women, as a kind of strategic essentialism. For instance, when my interlocutor Justina travels to bring contraband, she always dresses in her pollera, and on top of her contraband goods, she places agricultural products from her land in the border village, Yapita. In this manner, public functionaries are more likely to consider her as a 'humble farmer woman'. This strategic use of identity markers can be related to the ways in which women are ascribed a particular 
symbolic significance in representations of the Andean, as 'uncontaminated' by colonisation, hybridisation and geographical displacement (Crain 1996). According to Crain, this image can be seen as part of a strategic essentialism in order for women to gain a voice in a post-colonial context, as well as extend their employment opportunities in urban contexts (1996:137). It reflects how projects of subjectification in this context entail a binary logic of classification, situating persons as either mestiza woman or indigenous woman, positions that may involve different claims for being 'citizen' or 'legal'. The mestiza or tourist-looking woman may more easily be allowed to pass as 'legal', while the indigenous women may be allowed to pass for simply being situated 'outside'. The chola in contrast, as located in-between these categories, does not fit either, and may, as illustrated in the case of Dorothea mentioned earlier, be more easily suspected to work illegally. Specific constructions of womanhood and racialised identities are thus actualised and enacted in vendors' encounters with public officials, as categories of identity are made relevant in attempts to mediate between informality and official requirements. While they may appear as 'perfect neoliberal citizens' as noted in the introduction, they simultaneously oppose and circumvent the demands of the state's neoliberal regime, by drawing on relational as well as symbolic resources. Hence, informal trade is constructed and reconstructed as a particular feminine and racialised realm. As we shall see in the next section, recent economic policies contribute to skew some of these symbolic multiplicities by intensifying mechanisms of exclusion and inclusion, and to 'un-make' women vendors as apparently 'perfect neoliberal subjects'.

\section{The Regime of Flow and Regulation}

During the last few years, Peruvian authorities have increased border controls, and measures have been taken to formalise commodity flows and modernise the border control system. This has partly been in response to demands from the USA, with which Peru in 2006 signed a trade promotion agreement (ratified in 2009). As part of this agreement the USA is to assist Peru in limiting exportation of narcotics, modernising the equipment and procedures of the National Police and Customs Agency, and strengthening the rule of law. These dimensions of trade agreements indicate how, as previously noted, the current liberalisation of the market worldwide is accompanied by an increasing significance ascribed to formality and the legal. In addition to strengthening and modernising checkpoints at the 
borders, Peruvian authorities have also placed checkpoints along the highways before entering the big cities, and, as previously noted, policies have been implemented to formalise economic activities. In addition, routines for the registration (and destruction) of confiscated goods have been introduced to reduce the problem of functionaries who take confiscated goods for themselves.

With stricter control and regulation of commodity flows at the borders and beyond, the advantages of bringing contraband from Bolivia and Chile seem to be in gradual decline. In Arequipa, many people who ran relatively large contraband businesses, from a local point of view, told me that they were downsising or leaving their businesses. One of them is Camila, a woman regarded as a grand business woman among her colleagues at the Feria. She brings leather jackets from Bolivia, which she buys for 120 soles and sells for about 300 soles. She used to earn well, bringing 300 jackets at a time, but now that the border controls have increased she brings only 20 or 30 . Other contrabandistas have decided to stop bringing contraband altogether, and formalise their businesses. For instance, Dorothea, after repeatedly having her goods confiscated, invested in a copy machine and started selling authorised office equipment. After formalising, however, her earnings declined and she decided to invest in an informal mining project to compensate. This investment proved to be more hazardous than any of her previous ventures, however. As in Dorothea's case, many contrabandistas feel forced to formalise in response to increased border controls, but suffer a loss of income as a result. Formalisation may thus pose new and unforeseen challenges and dilemmas.

After Peru signed a free trade agreement with China in 2009, China was expected to replace the USA as Peru's most important bilateral partner, a prospect which might seem ever more likely now after Trump has been elected president. The agreement with China contributes to facilitate the exportation and importation of Chinese goods and has contributed to an increase of importation especially of textiles to Peru. The agreement involves reduced import taxes and specifies the possibility of refunding these taxes on a long-term basis. Some of the people I interviewed argued that the agreement would give Peruvians great opportunities to earn money through importation, and there was almost no end to their ideas for new business ventures. This optimism was especially widespread among the young and middle class in Lima, but less so in Arequipa. 
Seen from the perspective of contrabandistas in Arequipa, the free trade agreement with China has resulted in more competition from grand-scale actors whose activities depend less on chains of local intermediaries, and importing directly (and formally) from overseas. As a result, vending activities seem to become increasingly centred around Lima, as more goods are brought in directly and legally through the capital. So, while people used to come to Arequipa-even from Lima-in order to buy contraband goods, opportunities related to cross-border trade with Bolivia and Chile are in decline. The activities of contrabandistas are thus increasingly restricted, as their reliance on small-scale, informal and socially embedded forms of trade is complicated by a strengthening of controls as well as increased competition.

While there is an expectation that free trade agreements will break down the limitations on trade across borders, the situation of contrabandistas shows that such agreements may contribute to open up some borders while increasingly restricting others, and opening up trade channels for some, but restricting them for others. Hence, while accommodating legal importation, the business opportunities offered through these agreements seem to be limited to the middle/upper-classes. Indeed, free trade agreements can be seen to produce specific sorts of 'governable spaces' (Watts 2004) where trade is allowed to happen only in specific, pre-defined ways, while excluding other forms of trade from the same spaces. In the Peruvian context, the mechanisms of inclusion and exclusion that are thus created must be understood in terms of their gendered effects, as the agreements increasingly constrain the small-scale, unskilled and more localised forms of trade dominated by women. Overseas importation demands higher financial investments and greater knowledge of national regulations and procedures of importation. Legal imports thus contrast sharply to the localised and often small-scale modes of bringing contraband from neighbouring countries, which rely firstly on social networks. The greater importance of overseas importation may therefore serve to exclude actors who lack capital and knowledge. Indeed, free trade agreements may put particular constraints on regional cross-border trade in ways that are likely to affect, particularly, women reliant on this kind of economic activity. The regulation and formalisation of trade (through, for instance, free trade agreements) may thus marginalise many women further and render their market work even more ambiguous as work. In this regard, Peru's signing of free trade agreements in recent years represents an accentuation of the country's insertion into global 
markets in a way that puts new demands on the 'perfect neoliberal citizen', and with the potential of fortifying certain forms of inequality. It indicates how economic policies and processes are moulded by and through existing social relations and institutions, and hence play out in spaces that are created through, and contributing to reinforce, relations and categorisations connected to class, gender, and 'race'.

\section{Conclusions}

Exploring how economic activities at the margins of the formal economy are socially embedded and informed by existing social relations and institutions of various kinds, this chapter has argued that policies for the promotion of entrepreneurship and formalisation cannot be considered a historically and socio-culturally neutral or isolated process. The chapter has therefore sought to provide an ethnographic exploration of the class, ethnic and gender relationships in which these economic activities are actualised. These are important aspects to take into account if we are to understand the proliferation of Peru's so-called culture of informality, and how it is constituted and affected by neoliberal reforms and ongoing policies for entrepreneurship, formalisation and regulation.

There are significant class, racialised and gendered dimensions to the ways in which vending and contraband in Peru are practised and negotiated, illustrated not only by many people's lack of other alternatives to earn an income, but also by how vendors draw upon relational and symbolic resources in their economic strategising. The chapter has therefore demonstrated how vendors seek to mediate between official demands and informal dimensions of vending by relying on social relations and particular enactments of womanhood and racialised identities. While the view of vending as an extension of domestic activities may contribute to devalorise women's work, I have illustrated how women may also seek to enact these particular constructions of womanhood in attempts to facilitate vending at the margins of the formal. By evoking a notion of womanhood as mother, and more specifically the poor mother's suffering and sacrifice, vendors plead that vending is their only way to earn a living. In this and other ways, they seek to make it more difficult for public functionaries to interfere, by actualising and enacting an image of womanhood that has long been considered central in Latin America for making political claims. Drawing on particular gendered and racialised identities and stereotypes, vendors try to avoid and circumvent official interference. 
Through their economic strategising and tactics, vendors both subscribe to-and oppose-the stereotypical expectation towards the chola as well as the demands to the 'perfect neoliberal' citizen, but increasingly so with a risk of being criminalised, as I demonstrated in the last part of the chapter.

While women's activities in market work and contraband is ascribed an ambiguous status as work, there have been continual attempts in recent years to include such activities in state regimes of regulation and control. The stimulation of entrepreneurship and market liberalisation initiated by Fujimori in the 1990s has thus gradually been accompanied by measures to promote the formalisation of unauthorised businesses and border controls. Aiming to promote 'development', security for owners and a more effective land market, such measures may, however, contribute to fortify existing fissures along class, ethnic and gender lines, and result in further exclusion, even criminalisation, of vendors. With the signing of free trade agreements in recent years, we see yet an example of how market liberalisation operates through an increased significance ascribed to formality and the legal. While such agreements are contributing to facilitate Peru's access to global markets, several contrabandistas experience their businesses to be negatively affected, due to the strengthening of border controls and increased competition from overseas importation. By this I do not intend to romanticise entrepreneurship at the margins of the legal, but rather to demonstrate how small-scale entrepreneurs from the working classes may be affected in very different ways than grand-scale entrepreneurs. In particular, considering that vending activities in this context are actualised through relations and categorisations connected also to gender and racialisation in specific ways, the promotion of formalised, overseas importation may have particular gendered and racialising effects. It is therefore important to acknowledge, in discussing Peru's now long-standing promotion of market liberalisation, how the production of specific sort of 'governable spaces' may serve to exclude certain actors and forms of economic activities from the same spaces, and, as a result, reinforce longstanding economic and socio-cultural inequalities.

\section{Note}

1. Altiplano refers to the presence of vendors and goods from the Andean highlands. 


\section{REFERENCES}

Babb, Florence. 2001. Market/Places as Gendered Spaces: Market/Women's Studies over Two Decades. In Women Traders in Cross-Cultural Perspective: Mediating Identities, Marketing Wares, ed. L. Seligmann, 229-240. Stanford: Stanford University Press.

Bear, Laura. 2014a. Capital and Time: Uncertainty and Qualitative Measures of Inequality. The British Journal of Sociology 65 (4): 639-649.

- 2014b. For Labour: Ajeet's Accident and the Ethics of Technological Fixes in Time. Journal of the Royal Anthropological Institute 20 (S1): 71-88.

Carsten, Janet. 2004. After Kinship: New Departures in Anthropology. Cambridge: Cambridge University Press.

Comaroff, Jean, and John Comaroff. 2006. Law and Disorder in the Postcolony. London/Chicago: The University of Chicago Press.

Crain, M. 1996. The Gendering of Ethnicity in the Ecuadorian Andes: Native Women's Self-Fashioning in the Urban Marketplace. In Machos, Mistresses and Madonnas: Contesting the Power of the Latin American Gender Imagery, ed. M. Melhuus and A.K. Stølen, 134-158. London: Verso.

de Soto, Hernando. 1989. The Other Path: The Invisible Revolution in the Third World. London: Taurus.

- 2001. The Mystery of Capital. Why Capitalism Triumphs in the West and Fails Everywhere Else. London: Black Swan.

De la Cadena, Marisol. 1995. Women are More Indian: Ethnicity and Gender in a Community Near Cuzco. In Ethnicity, Markets and Migration in the Andes: At the Crossroads of History and Anthropology, ed. B. Larson and O. Harris, 329-348. Durham: Duke University Press.

Ewig, Christina. 2010. Second-Wave Neoliberalism: Gender, Race, and Health Sector Reform in Peru. University Park: The Pennsylvania State University Press.

Gandolfo, Daniella. 2013. Formless: A Day at Lima's Office of Formalisation. Cultural Anthropology 28 (2): 278-298.

Goddard, Victoria. 2000. The Virgin and the State: Gender and Politics in Argentina. In Gender, Agency and Social Change: Anthropological Perspectives, ed. Victoria Goddard, 221-249. London/New York: Routledge.

Harris, Olivia. 2000. To Make the Earth Bear Fruit: Ethnographic Essays on Fertility, Work and Gender in Highland Bolivia. London: Institute of Latin American Studies, University of London.

Holston, James. 2008. Insurgent Citizenship. Princeton/Oxfordshire: Princeton University Press.

Kabeer, Naila. 2010. Gender and Social Protection Strategies in the Informal Economy. London/New York/New Delhi: Routledge. 
Larkins, Erika R. 2015. The Spectacular Favela. Violence in Modern Brazil. Oakland: University of California Press.

Lazar, Sian. 2008. El Alto, Rebel City. Self and Citizenship in Andean Bolivia. Durham/London: Duke University Press.

Leacock, E. 1972. Introduction. In The Origin of the Family, the State and Private Property, ed. F. Engels, 7-67. New York: International Publishers.

Matos Mar, José. 1984. Desborde Popular y Crisis del Estado. El Nuevo Rostro del Perú en la Decada de 1980. Lima: Instituto de Estudios Peruanos.

Mitchell, Timothy. 2002. Rule of Experts: Egypt, Techno-Politics, Modernity. Berkeley: University of California Press.

Ødegaard, Cecilie Vindal. 2010. Mobility, Markets and Indigenous Socialities: Contemporary Migration in the Peruvian Andes. Burlington: Ashgate Publishing.

. 2016. Made in China. Contraband, Labor, and the Gendered Effects of 'Free-Trade', China-Peru. Journal of Development Studies, published online 29 June, $1-15$.

Polanyi, K. [1944] 2001. The Great Transformation: The Political and Economic Origins of Our Time. Boston: Beacon Press.

Rivera Cusicanqui, S., and D.Y. Arnold. 1996. Ser mujer indigena, chola y birlocha en la Bolivia postcolonial [To Be a Woman; Indigenous, Chola and Westernised in Postcolonial Bolivia]. La Paz: Ministerio de Desarrollo Humano.

Roberts, Bryan R. 1995. The Making of Citizens. Cities of Peasants Revisited. London: Edward Arnold.

Rousseau, Stephanie. 2007. The Politics of Reproductive Health in Peru: Gender and Social Policy in the Global South. Social Politics 14 (1): 93-125.

Sacks, Karen. 1974. Engels Revisited: Women, the Organization of Production and Private Property. In Woman, Culture and Society, ed. M. Rosaldo and L. Lamphere, 207-222. Palo Alto: Stanford University Press.

Scott, James. 1998. Seeing Like a State: How Certain Schemes to Improve the Human Condition Have Failed. New Haven: Yale University Press.

Seligmann, Linda. 2004. Peruvian Street Lives: Culture, Power, and Economy Among Market Women of Cuzco. Urbana/Chicago: University of Illinois Press.

Sieder, Rachel, Line Schjolden, and Alan Angell, eds. 2005. The Judicialization of Politics in Latin America. New York/Hampshire: Palgrave Macmillan.

Watts, M.J. 2004. Resource Curse? Governmentality, Oil and Power in the Niger Delta, Nigeria. Geopolitics 9: 50-80.

Weismantel, Mary. 2001. Cholas and Pishtacos: Stories of Race and Sex in the Andes. Chicago/London: University of Chicago Press.

Yanagisako, Sylvia. 1987. Mixed Metaphors: Native and Anthropological Models of Gender and Kinship Domains. In Gender and Kinship: Essays Toward a Unified Analysis, ed. J. Collier and S. Yanagisako, 86-118. Palo Alto: Stanford University Press. 
Open Access This chapter is licensed under the terms of the Creative Commons Attribution 4.0 International License (http://creativecommons.org/licenses/ by $/ 4.0 /$ ), which permits use, sharing, adaptation, distribution and reproduction in any medium or format, as long as you give appropriate credit to the original author(s) and the source, provide a link to the Creative Commons license and indicate if changes were made.

The images or other third party material in this chapter are included in the chapter's Creative Commons license, unless indicated otherwise in a credit line to the material. If material is not included in the chapter's Creative Commons license and your intended use is not permitted by statutory regulation or exceeds the permitted use, you will need to obtain permission directly from the copyright holder.

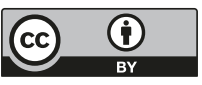

